\title{
FNGOs and financial inclusion: investigating the impact of microcredit on employment growth in Ghana
}

\begin{abstract}
Financial Non-Governmental Organisations (FNGOs) are regulated microfinance institutions (MFIs) that operate with a social welfare logic in the delivery of microcredit to the financially excluded in Ghana. The microcredit is aimed at supporting the financially excluded individuals to create sustainable Micro and Small Enterprises (MSEs) for the generation of both skilled and unskilled employment. From the institutional theory perspective, this study aims at investigating the impact of microcredit provided by FNGOs on employment growth among MSEs in Ghana. The major contribution of this study is the fact that, there is a little study on FNGOs and their impact on employment growth in the Ghanaian context. Therefore, this is one of the few studies which highlights the role of FNGOs in promoting financial inclusion through the provision of microcredit for employment generation purposes. Through a multiple regression analysis, the study uses primary data collected from 506 MSEs in Ghana. The results show that microcredit which is flexible in repayment mode, accessible, and adequate has a positive impact on employment generation among MSEs in Ghana. However, the current cost of microcredit in Ghana has a negative impact on employment growth among MSEs in Ghana.
\end{abstract}

Keywords: Employment Growth, FNGOs, Ghana, Micro and Small Enterprises, Microcredit, Financial Inclusiveness

Paper Type: Research Paper 


\section{Introduction}

Financial Non-Governmental Organisations (FNGOs) are poverty-reduction driven microfinance institutions (MFIs) that provide microcredit to the financially excluded individuals to engage in venture creation activities in Ghana. Through microcredit, the financially excluded can engage in self-employment and the generation of both skilled and unskilled employment for others (Bureau and Fendt, 2011; Sappleton and Lourenco, 2016). The creation of these employment opportunities is important because it offers the financially excluded a consistent income and livelihood which in most cases goes to positively affect the total wellbeing of the household (Wilson and Martin, 2015; Kolvereid, 2016). Research evidence provides some reasons for this financial exclusion in Ghana. Notably, individuals are excluded from the formal financial system in Ghana due to information asymmetry challenges, lack of credit history, the perceived risk associated with the entrepreneurial poor, weak or unavailable creditor protection systems and lack of the required collateral to secure loans from the formal financial systems coupled with the general moral hazard by the traditional financial system about the poor (Lash, 2008; Haag and Henschel, 2016). Pathak and Varshney (2017) intimate that remoteness from markets, inadequate access to suppliers, poor business infrastructure and a lack of skilled labour makes some individuals and their MSEs less attractive in sourcing finance from the commercial banks. Due to the above reasons, such excluded individuals turn to alternative sources for business finance such as from family and friends which might not be sustainable and sufficient for creating a venture (Palamida et al. 2017). FNGOs have therefore been instrumental in providing finance to these categories of individuals to engage in various venture creation activities with the intention of creating employment (Islam, Nguyen, and Smyth, 2015).

The main purpose for providing microcredit to MSEs is not far-fetched. Microcredit usually referred to as microfinance in its extended form denotes the provision of loans to the entrepreneurial poor to engage in an income generating activity (Dzansi and Atiase, 2014 (Mahmood, Hussain, and Matlay, 2014). Microcredit as a poverty reduction strategy emerged in the 1970s to combat poverty by way of increasing access to credit to the financially excluded individuals mainly in developing countries who live on less than \$1 per day (Mahmood et al, 2014; Rajbanshi et al., 2015). There is an extant literature that has emphasised this poverty reduction mission of microcredit especially for developing countries where many individuals are excluded from the formal financial systems (Khavul, 2010). In Ghana, microcredit clients are predominantly women in both rural and urban centres who are engaged in various activities such as farming, food processing, petty trading, manufacturing, hospitality services, 
educational and street vending activities (Addae-Korankye, 2012).

FNGOs are not only concerned about advancing microcredit to the entrepreneurial poor but are also interested in providing other non-financial services such as financial literacy, businessrelated training and in some cases health education (Habib and Jubb, 2013). FNGOs are therefore noted for using cost-effective and innovative ways to reduce poverty through the provision of microcredit and other related services to the socially excluded (Armendáriz de Aghion and Morduch, 2005). The intervention of FNGOs is important because, through FNGOs, MSEs can access adequate funding which is moderately cheap, accessible and adequate, with flexible repayment terms than other commercially oriented MFIs (Habib and Jubb, 2013). Thus, FNGOs provide the avenue through which financial inclusion is made possible in Ghana. Khavul (2010) indicates that since FNGOs are non-profit oriented, they are likely to be more sustainable in their drive towards poverty reduction and financial inclusion than the profit-seeking financial institutions.

The main objective of this study is to investigate the impact of microcredit provided by FNGOs on employment generation among MSEs in Ghana. This study has two main contributions to offer. Firstly, studies relating to FNGOs and their impact on the generation of both skilled and unskilled employment in Africa is scarce and limited (Amoako and Matlay, 2015). As far as this study is concerned, very little studies in the Ghanaian context have focused on FNGOs and their unique role in the development of MSEs (Dichter, 1999). This study, therefore, aims at contributing to the entrepreneurial finance literature by highlighting the role of FNGOs in the provision of microcredit to MSEs to support employment generation in Ghana. Secondly, even though the entrepreneurship literature indicates that MSEs contribute to employment generation in developing countries (Sappleton and Lourenco, 2016), research on the role of microcredit in employment generation among MSEs particularly in the African context is weak (Nagler and Naudé, 2016; Syed and Faisal, 2011). This study, therefore, contends that MSEs in Ghana are able to generate both skilled and unskilled employment for individuals and their households which promotes financial inclusiveness (Kessey, 2014). It, therefore, highlights the employment generation capacity of MSEs in Ghana. 


\section{Background}

\section{Promoting financial inclusion through microcredit}

Financial inclusion as a concept refers to the process which ensures access to adequate credit and other financial services by vulnerable groups at reasonable costs and standards without further widening the access gap (Claessens, 2006; Ambarkhane et al. 2016). Financial inclusiveness is an important growth strategy to foster economic development through an equitable sharing of national financial resources. Sarma and Pais (2011) argue that financial inclusion in a country promotes entrepreneurial activities in the sense that individuals can have adequate access to financial capital to engage in venture creation. It is important to also note that, an inclusive financial system allocates productive resources in an economy, improves national financial management, promotes the advancement of savings practices, and helps in the reduction of informal credit (Ndlovu, 2013). Undeniably, it has been observed that countries with larger financial inclusive systems grow faster than those without (Radhika and Ghosh, 2013; Kima, Yub, and Hassan, 2018). More importantly, an inclusive financial system creates a formal identity for access to formal resources such as access to payment services, savings and insurance for the under or unbanked population in a country (Ambarkhane et al. 2016). Globally, research has shown that the poor and vulnerable people are the most excluded from benefiting from formal financial systems (Helms, 2006; Deb and Suri, 2013). This exclusion whether partial or total remains the main obstacle to sustainable poverty reduction particularly in developing countries such as Ghana (Akpalu et al., 2012; Baklouti and Abdelfettah, 2013). Microcredit, therefore, became a necessary tool to serve the poor and the unbanked who lack access to credit to create and manage their MSEs for the purposes of generating an employment for themselves and others (Laha and Kuri, 2015; Dorfleitner et al., 2017). Through microcredit, many poor individuals are able to build assets for themselves, improve their consumption and in most cases are able to mitigate the effect of household shocks (Islam, Nguyen, and Smyth, 2015). Financial inclusiveness can therefore not become a reality without an effective microcredit strategy particularly for developing countries such as Ghana (Helms, 2006; Dzansi and Atiase, 2014).

FNGOs in Ghana usually adopt group lending method popularly known as the Trust Bank system which is seen as an effective strategy in developing the needed social capital for the entrepreneurial poor (Permanyer, 2014). A typical group consists of 10-20 borrowers who are taken through series of business training programmes before disbursement of the loan is done. An average loan size ranges between $\$ 100$ and $\$ 500$ with a repayment period spanning between 4 and 6 months with an average interest rate of $4 \%$ per month(Ganle et al. 2015). For the 
purposes of regulation and monitoring by the Central Bank of Ghana, FNGOs are classified either as Tier II or III institution with variations in their minimum capital, the focus of activity and operational zone (Bank of Ghana, 2015).

\section{MSEs and employment generation in Ghana}

There is an abundance of evidence in the entrepreneurship literature which suggest that MSEs, in both developed and developing countries contribute to economic development, job creation as well as poverty reduction among its citizens (Bureau and Fendt, 2011; Bauchet and Morduch, 2013; Farja et al., 2017). For instance, MSEs account for 92\% of businesses and provides $85 \%$ of all manufacturing jobs in Ghana. Similarly, MSEs also contribute $70 \%$ to Ghana's Gross Domestic Product (Agyapong, 2010; Amoako and Matlay, 2015). MSEs are defined severally depending on the country and the geographical location in context. Usually, MSEs are defined using their number of employees and total assets (Brinkmann et al., 2014). In Ghana, a microenterprise is defined as any firm employing up to 5 employees or has fixed assets excluding land and building not exceeding $\$ 10,000$ (Buame, 2012). Similarly, a small enterprise is defined as any firm employing between 6 and 29 or having fixed assets excluding land and building not exceeding \$100,000 (Amoako and Matlay, 2015). Micro and small enterprises still form a dominant part of the Ghanaian economy. About 3,200,000, representing 46 percent of all households in Ghana, operate some form of non-farm enterprises with women operating 72 percent of these businesses (Ghana Statistical Service, 2010). Mensah (2004) recounts that $90 \%$ of registered firms in Ghana are MSEs. This implies that the Ghanaian economy is highly dependent on the contribution from MSEs in terms of economic growth and employment generation. However, access to cheap credit by MSEs in Ghana to engage in meaningful employment and income generation activity remains a hurdle to their growth (Abor and Biekpe, 2006). This makes the financial services provided by FNGOs very crucial in the creation of employment and other perceived benefits from the operation of MSEs to the financially excluded. MSEs can be home-based, farm-based or can be street-front business operated mainly by their owners on a full- time or part-time basis (Faherty and Stephens, 2016). In some cases, the owners employ non-owner managers to undertake the daily functions of the business if the principal owners have other competing interests that prevent them from taking an active role in the management of the MSE (Lorenz et al. 2015). 


\section{Financial inclusion and employment growth}

The literature on financial inclusion emphasises that access to the appropriate, adequate, fair and equitable formal financial resources in a country contributes to economic growth and employment generation particularly among the poor who are usually at the margins of society (Lenka and Sharma, 2017). This is because, access to financial resources enables individuals to engage in various kinds of entrepreneurial activities which creates employment opportunities for themselves and others (Fan and Zhang, 2017). By so doing, the financially excluded individuals would be able to overcome poverty through the engagement in enterprise creation which generates a consistent income for themselves and their households (Swamy, 2014; Hajilee, Donna, and Metghalcji, 2017).

Typically, low employment generation which is commonly found in developing countries such as Ghana is usually associated with low financial penetration where the majority of the citizens are excluded from the formal financial system which disengages enterprise creation (Sarma and Pais, 2011). More importantly, the informal sector which takes the dominant share of the economy in developing countries and contributes a sizeable portion of the employment opportunities in these economies need to be supported. Therefore, supporting individuals in this sector to participate fully in the formal financial system encourages better prospects in terms of employment creation in the sector (Babajide, Adegboye, and Omankhanlen, 2015). It is expected that when individuals are provided with the necessary financial resources, they are able to engage in various forms of investments which provides diverse forms of employment in an economy (Figart, 2013; Ogechi and Evans, 2017). Sarma and Pais (2011) also argue that most individuals are financially excluded in a country because they lack employment which could serve as a guarantee for any borrowing activity. Therefore, if such individuals are given the opportunity to access formal financial resources despite their peculiarities and vulnerabilities, they would be able to engage themselves in at least a self- employment which contributes to economic growth in a country. A study which investigated the relationship between the financial development of a country and economic growth among 11 countries of MENA (Middle East and North Africa) region found that a less financially developed economy which excludes a lot of individuals does not promote economic development and employment growth (Kima, Yub, and Hassan, 2018). 


\section{Theory and hypotheses development}

The Institutional theory and the provision of microcredit in Ghana

Entrepreneurial research often seeks to analyse the various external environmental conditions which affect the growth of entrepreneurship and access to resources in a country. Research evidence suggests that various environmental factors affect the way entrepreneurs behave and exploit entrepreneurial opportunities (North, 1990; Scott,1992; Naude 2010). Institutional theory has, therefore, become one of the common lenses through which various researchers account for the environmental influences on entrepreneurial activities and access to important resources that entrepreneurs need (Bruton et al. 2009; Su et al., 2016). The theory also emphasises institutional void in a country whereby institutions which are responsible for the growth of MSEs and the provision of the required resources such as financial capital are either weak or totally unavailable (Sutter et al., 2013). An institutional environment of a country is considered weak if it lacks the necessary capacity to ensure that markets work effectively or if actions or inactions of institutions undermines these markets and thereby stifles the whole system (Kistruck, et al, 2015). In North's perspective, once the institutional framework of a country is created, it establishes the incentive system, defines property rights, access to financial resources, access to markets, standards of production and safety standards and many other regulatory mechanisms which affect the operation of MSEs.

Institutions play an important role in the development of the financial sector of every country. The case of Ghana is not different. The formal financial services in Ghana such as the commercial banks have consistently excluded the MSE sector in their lending activities (Gyamfi, 2012). Whatever the reasons that are offered, this situation stifles national economic development as well as the development of the MSE sector to contribute to economic growth and employment generation. Various lending regulations in the Ghanaian commercial banking sector does not take into consideration the peculiar nature of the MSE sector hence the current challenges the sector is facing when it comes to access to financial resources to engage in any income generating activity (Abor and Quartey, 2010). In most cases, due to the vulnerability and the high attrition rate of the MSE sector in Ghana, most financial institutions do not have the necessary mechanisms to manage the risk which is associated with this sector. This implies that most formal financial institutions are ineffective in extending credit to MSEs due to their inability to design and manage loan products which suit the sector.

Typically, FNGOs are influenced by regulatory institutions which seek to bring pressure on them to change behaviour and structures in the delivery of microcredit to MSEs (North, 1990). 
According to Shughart and Thomas (2014), FNGOs can experience a top-down imposition of rules where state institutions attempt to exert pressure for conformity to rules and policy guidelines. For instance, the introduction of the licensing requirement for FNGOs in 2011 saw the exit of many FNGOs hence their inability to serve the financially excluded (Bank of Ghana, 2015). In most cases, some of these regulations may not work in the interest of the financially excluded in their bid to engage in income-generating activities. More so, the cost of credit in Ghana has become so expensive for MSEs to borrow for any kind of investment to generate the needed employment. This situation is attributed to the ineffective financial structure of the country, structural rigidities and inefficiencies of the banking sector to financially include the MSE sector adequately (Quartey, 2003; Abor and Quartey, 2010).

In addition, various other factors can affect financial institutions including FNGOs in their delivery of financial services to MSEs. Wilson and Martin (2015) explain that factors such as access to technology, frequent political changes, high population growth, are noted to influence the delivery of credit in a country. More so, excessive bureaucracy, corruption and high taxation could influence FNGOs and their ability to provide credit to MSEs effectively (Alajaty,2017). These obstacles and its associated excessive business restrictions hinder the effectiveness of the financial system in Ghana and this affects access to resources and the growth of MSEs (Shirokova and Tsukanova, 2013). It is therefore important for public policy to be directed towards MSE development and general entrepreneurship development both at the national level and local levels by providing the right support and resources in an anticipation for job creation (Nielsen, 2016; Palamida et al. 2017). Since microcredit is an enabler of entrepreneurial activities among MSEs in Ghana, this study postulates that there is a positive relationship between microcredit provided by FNGOs and employment growth among MSEs. The hypotheses are therefore presented below.

\section{The cost of credit and employment growth among MSES}

In developing countries where financial penetration and access to formal financial resources are low, many individuals have no other choice than to depend on informal financial sources such as microcredit in order to tap into any business opportunity. In most cases, these informal sources are expensive and affect the profitability of the enterprise as well as its ability to create more employment (Jahiruddin, Short, Dressler, and Khan, 2011). Compared with larger firms, MSEs face more a critical situation since they usually have insufficient equity to boost their operations (Beck, Demirgüç-Kunt, and Maksimovic, 2008). Pavlov, Poutziouris, and Soufani 
(2004) argue that small firms finance more than 50\% of their operations through expensive lines of credit which might have a negative impact on their profitability. Therefore the cost of credit is regarded as one of the important factors which negatively affects the operation of MSEs in Africa (Fatoki and Odeyemi, 2010). Rokhim et al. (2016) also extended the cost of credit to include the usual transaction cost which includes high transportation cost and time spent on following up on the loan application which ultimately increases the cost of access to credit. In order to reduce the cost associated with lending to MSEs, Berger and Udell (2006) advice that there is the need for financial institutions to use various innovative mechanisms such as improving their lending infrastructure and relationship building to reduce the cost of lending to MSEs.

In the case of Ghana, the cost of credit is regarded as one of the most important factors which negatively affects the operation and profitability of MSEs and the promotion of an inclusive financial system (Egyir, 2010). When MSEs are less profitable, their ability to generate more employment in an economy is hindered. Indications from the World Competitive Index reports and the various surveys by the Ghana Association of Industries show that the cost of credit has persistently been high and this has been considered as the main obstacle to investment and economic growth in Ghana (Kwakyi, 2012). This high cost of borrowing is attributed to the competitive borrowing by the central government and other structural inefficiencies in the banking industry. MSE owners in Ghana, therefore, borrow at a high cost which increases their operational cost and in effect affect their profitability (Quartey, 2003; Abor and Quartey, 2010). In developing entrepreneurial opportunities as part of the effort to generate employment in Ghana, access to affordable and bearable credit, with adequate support systems is imperative (Ghosh and Tassel, 2013). This implies that the institutional environment which ensures the provision of credit to MSEs is imperative if employment creation should be a reality (Shirokova and Tsukanova, 2013). Commercial banks and other microfinance institutions need to be regulated by the Central Bank of Ghana in such a way that the cost of credit does not undermine the growth of MSEs in their attempt to generate employment. Based on the above discussion and evidence in the literature, the study hypothesised as follows:

$\boldsymbol{H}_{1 a}$ : Cost of credit is negatively related to employment growth of MSEs in Ghana. 


\section{The flexibility of loan repayment and employment growth among MSEs}

The design and availability of flexible loan products for the financially excluded have an impact on financial inclusion and employment generation in a country. MSEs especially the younger ones which have access to a microcredit with a flexible loan repayment conditions perform better in employment generation and other outcomes than those without (Duan et al., 2009). Meyer (2002:351) intimates that providing standardised loan products with a "one-size fits all' loan terms and condition may increase the risk of lending to the entrepreneurial poor as well as endangering their businesses which will negatively affect the creation of employment opportunities in a country. Wright (2000) therefore argues that the lack of flexibility of loan product design is one of the most important issues affecting financial inclusiveness in developing countries. The expectation is that MFIs including FNGOs are supposed to design suitable financial products which meet the peculiar needs of MSEs in terms of interest rates, repayment schedules, loan administration and even the loan approval process (Meyer, 2002). Loan product flexibility also has the tendency to increase patronage of such products and thereby reducing dropout rates from microfinance programmes and this promotes the financial inclusiveness in a country. It is therefore expected that commercial banks and other financial institutions operating in Ghana offer flexible loan products to MSEs which does not deny enterprises from contributing effectively to economic growth and employment generation. Based on the above discussion and evidence in the literature, the study hypothesised as follows:

$\boldsymbol{H}_{1 b}$ : Flexibility of loan repayment method is positively related to employment growth of MSEs in Ghana.

\section{Loan adequacy and employment growth among MSEs}

MSEs are usually faced with under-financing difficulties which inhibits their ability to expand their operations and this discourages the engagement of more employees (Islam, Nguyen, and Smyth, 2015). It has been argued that, due to the high attrition rate of MSEs in developing countries, lenders do not extend the amount of loan which is needed to drive the MSE adequately (Beck and Demirguc-Kunt, 2006; Donou-Adonsoua and Sylwester,2016). When this happens, it affects the growth of MSEs and their ability to enjoy economies of scale in their operations. In some other cases, loans acquired from MFIs get diverted into other non-business related activities if MSE owner observes that the loan acquired does not meet the needs of the enterprise. 
However, adopting the appropriate credit risk management methods will provide the right assurance to both the lending institution as well as the MSEs. Loan adequacy for MSEs in Ghana has been an issue of concern for the growth of the sector. Research shows that most MSEs borrow from multiple sources due to the inadequacy of the loans received from their principal institutions (Baklouti and Abdelfettah, 2013). Due to the risky nature and the poor survival rate of MSEs in Ghana, most financial institutions are hesitant to offer loans that could adequately meet their financial and expansion needs. In most cases, financial institutions do not consider very important factors such as the size of the business, and the purpose of the loan in the loan granting process. When loans are reduced abruptly without considering the above factors, it seizes to meet the needs of the MSEs. Financial institutions in Ghana usually cite inadequate borrower identification, poor attitude towards credit, and poor loan recovery mechanisms as reasons for denying MSEs of adequate loans for business expansion purposes (Kwakyi, 2012). However, Ayayi (2012) suggest that financial institutions should use pro-poor credit risk management methods such as the provision of managerial training, regular loan monitoring and group lending to manage such risks associated with MSEs. This will provide the confidence to financial institutions to extend the needed credit to MSEs. More importantly, the institutional environment which ensures that MSEs have access to adequate funding need to be driven by public policy (Nielsen, 2016). By doing this, public policy should be used to drive the financial inclusion agenda. Based on the above discussion and evidence in the literature, the study hypothesised as follows:

\section{$\boldsymbol{H}_{1 c}$ : Loan amount adequacy is positively related to employment growth of MSEs in Ghana.}

\section{Loan accessibility and employment growth among MSES}

A well-functioning financial system which provides adequate access to financial resources promotes economic growth and employment generation, particularly in developing countries where access to credit is limited (Andrianova et al., 2008). The type of financial access gap which exists in developing countries has the potential to perpetuate poverty and widen the gap between the rich and the poor (Wellalage \& Locke, 2017). Similarly, MSEs who do not have adequate access to credit facilities are bound to face difficulties in raising enough financial capital to add to their meagre equity base (Carbo-Valverde, Rodrguez-Fernandez, Francisco, \& Udell, 2016). The situation is not different in the case of Ghana. The reality is that MSEs which are the main engine of growth in Ghana, are impeded by their lack of access to credit needed to support their growth (Snodgrass and Biggs, 1996). The challenge of limited access 
to credit has, therefore, made the process of raising seed capital for a venture extremely laborious, expensive, and sometimes discouraging to MSE owners (Hamilton and Fox, 1998). Accessibility to credit by MSEs, therefore, has the tendency to promote a financially inclusive system and the creation of employment opportunities for individuals. More often than not, the formal financial institutions are hesitant to extend credit to MSEs due to their failure rate, and lack of credit history. It has also been observed that MSEs lack the required collateral which is needed to secure loans from financial institutions in Ghana (Lash, 2008; Haag and Henschel, 2016). In some other cases, MSEs lack the audited financial statements which are often demanded by financial institutions for the loan appraisal system. Because of this, MSE owners usually depend on informal sources of financing such as from money lenders which are usually expensive. Therefore, the above factors coupled with a general moral hazard of the formal financial system against MSEs creates a barrier to financial inclusiveness (Mahmood et al., 2014). In dealing with accessibility to credit by MSEs in Ghana to promote a financial inclusive system, Kwakyi (2012) suggest a direct government intervention in the creation of a special fund purposely to support MSEs to grow. Based on the above discussion and evidence in the literature, the study hypothesised as follows:

$\boldsymbol{H}_{\text {ld: }}$ Loan accessibility is positively related to employment growth of MSEs in Ghana.

Figure I below show the proposed conceptual framework of the constituents of microcredit and employment growth of MSEs in Ghana. 


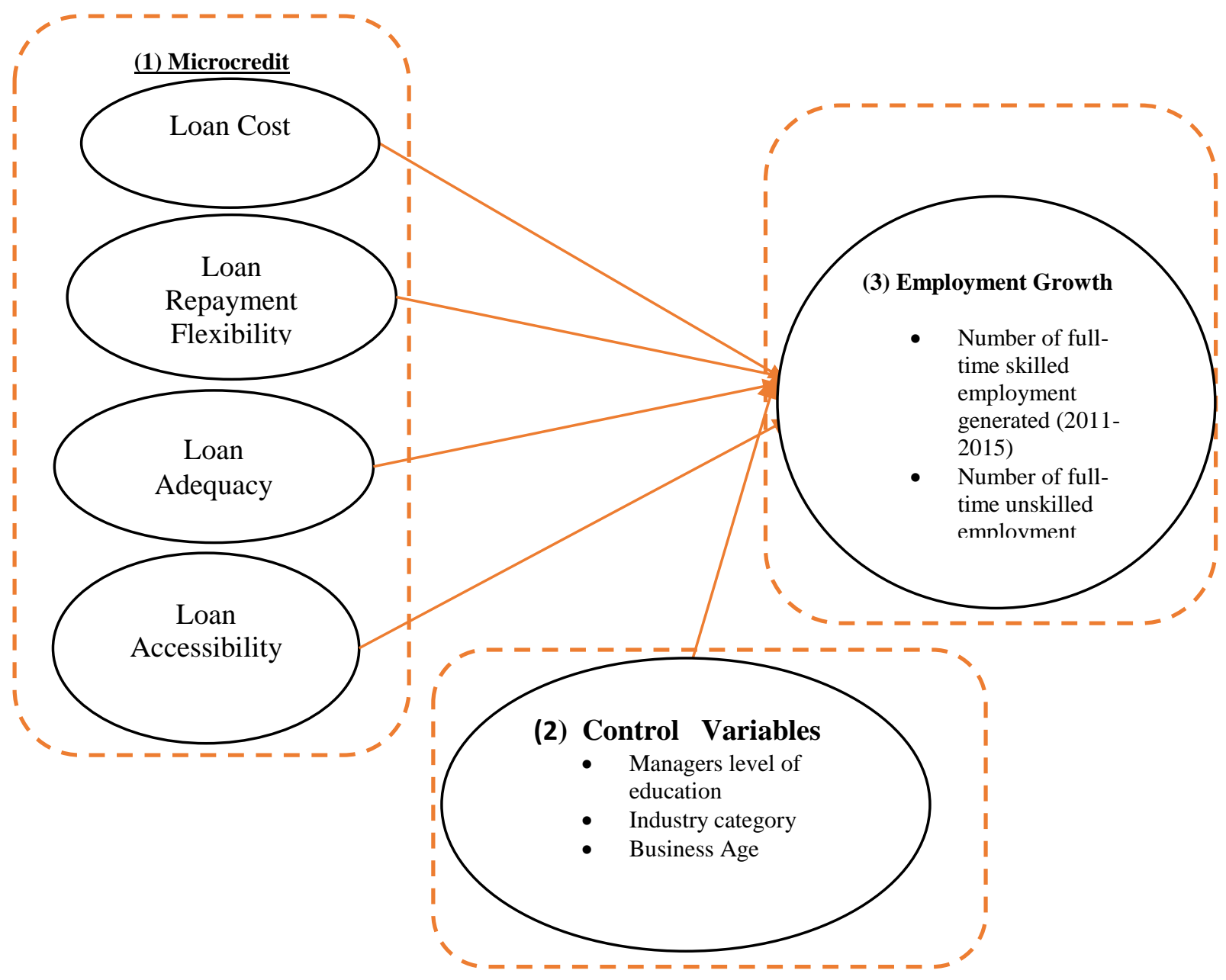

Figure I: A hypothesised model for the impact of microcredit on employment growth of MSEs in Ghana. 


\section{Research context and method}

\section{Sample and data}

This research was conducted in the Volta region which is one of the ten regions of Ghana. The Volta regions were selected for this study because, research evidence has shown that, it is one of the poorest regions in Ghana. The current rate of poverty incidence in the Volta region is $33.8 \%$ which is above the national average rate of $24.2 \%$ and the rate of vulnerability to poverty as high as 69\% (Novignon et al. 2012; Ghana Statistical Service, 2014). Secondly, due to the poverty menace in the region, it has become the destination for many FNGOs who are interested in reducing poverty with their outreach services. In addition, due to the presence of the Volta river in this region, a lot of entrepreneurial activities abound. Because of the above reasons, the Volta region was chosen for the study of financial exclusion and the impact of microcredit on employment generation.

The total clients of FNGOs in Ghana which represents the population for this study was 26,465. Also, a total of 4 stratum representing four separate groups of the 4 FNGO clients were identified. Based on these 4 stratum identified and using the sample size determination formula of Yamane (1967), 720 MSEs were sampled in March 2017 from a sample frame of 2,953. The samples MSEs were found in the agricultural, construction, hotels and restaurant, transport and distribution, general trading, general services and education sectors of the Ghanaian economy. General services represent business activities such as barber shops, hair salons, shoe repairs, communication services and such likes. General trading represents the sale of items such as foodstuffs, water, and firewood, Construction category represents manufacturing of building blocks, the sale of cement and sale of other building materials. Transport and distribution category represents taxi owners and commercial drivers. Hotels and restaurant category represent guest houses and, food services. The education category represents private basic schools only.

In April 2017, a questionnaire was sent to be completed by the 720 MSE owners in the Volta region. Out of these questionnaires sent out, 506 fully completed questionnaires were retrieved generating a response rate of $70.2 \%$. The survey has a high response rate because the researchers were able to meet participants during their loan group meetings which made it possible for the researchers to retrieve as many of them during their meetings. In conducting this study, a multiple regression analysis with a stratified random sampling (SRT) was adopted. Multiple regression analysis was used because the study sought to explain the relationship 
between employment which is the dependent variable and a number of explanatory variables such as loan cost, loan flexibility, loan amount and loan accessibility. SRT was adopted because the FNGOs engaged in this study were providing various kinds of products to very specific target markets. It is therefore convenient to categorise the clients of each FNGO into separate strata. To check the common method bias, an exploratory factor analysis using Principal Component Analysis of the microcredit factors was executed. From the process, no dominant factor emerged to explain a significant variance, hence common method bias is not a major concern for this study. Table I presents the profile of the sampled MSEs involved in this study.

Table I: Profile of sampled MSEs in Ghana

\begin{tabular}{lcc}
\hline Demographic Variables & Frequency & $\%$ \\
\hline Sectoral Distribution & 5 & \\
Agriculture & 10 & 1 \\
Construction & 22 & 2 \\
Hotels and Restaurants & 98 & 4.0 \\
Transport and distribution & 185 & 19.4 \\
General Trading & 178 & 36.6 \\
General Services & 8 & 35.2 \\
Education & & 1.6 \\
& & \\
Age of Business & 96 & 18.9 \\
6-10yrs & 307 & 60.7 \\
11-15yrs & 103 & 20.4 \\
16yrs+ & &
\end{tabular}

\section{Constructs and measures}

\section{Independent variables}

The study follows three main studies namely, Angelucci et al. (2015), Kistruck et al. (2015) and Mahmood and Rosli (2013) in the design of the microcredit as an independent variable. Based on this design, the study used four constructs and 12 items to measure the delivery of microcredit to MSEs in Ghana. The specific microcredit constructs include loan cost $(\boldsymbol{L C})$, flexibility of loan repayment method (FLR), loan amount adequacy (LAA) and loan accessibility $(\boldsymbol{L A})$. The independent variables were measured using a Likert scale anchored by strongly disagree(1) and strongly agree (5) indicating levels of agreement of MSE owners for each item measuring the use of microcredit provided by FNGOs in their business. Firstly, $L C$ measures three main categories of the cost associated with microcredit in Ghana namely loan 
interest, processing fees and loan deposit (cash collateral). Secondly, FLR has been measured using 3 items namely flexibility of repayment schedule, flexibility of loan repayment amount (instalment) and the convenience of loan term to meet business needs. Thirdly, LAM was also measured using 3 items indicating sufficiency of the loan amount for the business, satisfaction with the loan amount and whether the loan amount granted by the FNGO was less than the amount applied for. Finally, $L A A$ was measured using 3 items namely the ability to understand loan requirements, whether loan application and approval process were cumbersome and finally whether loans applied for were timely approved.

\section{Dependent variable}

One of the measures for measuring the growth or performance of a small business is the number of employees engaged in the business (Storey, 1994; Fatoki, 2011). Performance is defined as the results of activities of an organisation over a period under consideration (Fatoki, 2011). It has been noted that the measurement of employment has remained one of the major measures of performance among microcredit clients since this has always been a visible sign that such an enterprise can accommodate an extra expenditure on wages which signifies growth (Bögenhold and Fachinger, 2007; Magableh et al. 2011). Based on the above arguments, the study measured employment growth by capturing real employment data from MSEs for a period of five years (2011-2015). The five-year data is then aggregated to generate the average growth rate which has been used in the regression analysis.

\section{Control variables}

Several other factors apart from access to entrepreneurial capital are noted to affect the growth and performance of MSEs. Cooper et al. (1994) argue that MSE factors such as 'educational background of the entrepreneur, gender, management knowledge, specific industry knowledge, the age of business, access to the market as well as industry category' are all critical to the growth of MSEs. Other notable factors include enterprise size (Dickson et al. 2006), available social capital (Newman et al, 2014) and mode of entry of the entrepreneur (Parker and Praag, 2012). Based on the above evidence from the literature the study controlled for owner manager's level of education, industry category and business age.

\section{Exploratory factor analysis}


Following Anderson and Gerbing (1988), both factor analysis and reliability test were conducted to check the factorial structure and reliability of each construct. It is suggested that factors with low factor loadings $(<0.50$ for new models, $<0.60$ for existing models should be deleted first and data recalculated until a higher value of 0.7 and above is achieved (Hancock and Mueller, 2010; Sidek and Mohamad, 2014). A principal component analysis with varimax rotation was executed to examine the structure of microcredit. Four factors with an Eigenvalue greater than 1.000 arose and were consistent with the proposed constructs respectively representing loan cost, flexibility of loan repayment method, loan amount adequacy and loan accessibility (Kaiser-Meyer-Olkin statistic: 0.697; Bartlett Test of Sphericity: $\chi 2=3,473.472$, $\mathrm{df}^{1} 1 / 466, p=0.000$ ). The four factors explained a total of 77.991 percent of the variance. From the analysis, LC emerged as the most important factor with an Eigenvalue of 3.152, explaining $26.265 \%$ of the variance in microcredit and LA is the least important factor with an Eigenvalue of 1.562 and explaining $13.014 \%$ of the variance in microcredit. Table II below shows the items of the microcredit constructs as well as the loadings and cross-loadings for each item on factors. Items were only considered to have loaded properly if they had a loading of 0.200 or above on a factor and the difference between the main loading and other cross-loadings was more than 0.300 (Howell et al., 2005). Table 2 below shows the exploratory factor analysis of the microcredit factors. 
Table II: Exploratory factor analysis for microcredit factors

\begin{tabular}{|c|c|c|c|c|c|}
\hline & Variables & $\begin{array}{c}\text { Factor 1 } \\
\text { Loan }\end{array}$ & $\begin{array}{c}\text { Factor } 2 \\
\text { Loan }\end{array}$ & $\begin{array}{c}\text { Factor } 3 \\
\text { Loan }\end{array}$ & $\begin{array}{c}\text { Factor } 4 \\
\text { Loan }\end{array}$ \\
\hline (1) & Loan amount was sufficient for business & 0.127 & 0.059 & 0.929 & 0.006 \\
\hline (2) & Satisfied with loan amount & 0.104 & 0.017 & 0.916 & 0.029 \\
\hline (3) & Amount granted was less than applied & 0.032 & 0.138 & 0.788 & 0.111 \\
\hline (4) & Understands loan accessibility requirements & 0.078 & 0.061 & 0.018 & 0.762 \\
\hline (5) & Application process not cumbersome & -0.034 & 0.056 & -0.056 & 0.871 \\
\hline (6) & Timely approval of loan & -0.059 & 0.120 & 0.055 & 0.787 \\
\hline (7) & Affordable interest charges & 0.908 & 0.026 & 0.084 & 0.074 \\
\hline (8) & Bearable processing fees & 0.931 & 0.082 & 0.080 & 0.131 \\
\hline (9) & Affordable loan deposit & 0.859 & 0.024 & 0.101 & -0.148 \\
\hline (10) & Flexible loan schedule & 0.026 & 0.831 & 0.028 & 0.128 \\
\hline (11) & Affordable loan repayment & 0.058 & 0.928 & 0.107 & 0.078 \\
\hline \multirow[t]{8}{*}{ (12) } & Convenient loan term & 0.045 & 0.927 & -0.119 & 0.051 \\
\hline & Eigen Value & 3.152 & 2.698 & 1.948 & 1.562 \\
\hline & $\%$ of variance explained & 26.265 & 22.481 & 16.232 & 13.014 \\
\hline & KMO & 0.697 & & & \\
\hline & Bartlett's Test of Sphericity & & & & \\
\hline & Approx. Chi-Square & 3473.472 & & & \\
\hline & df & 66 & & & \\
\hline & sig & 0.000 & & & \\
\hline
\end{tabular}




\section{Reliability and validity Test}

The study utilised Cronbach's $\alpha$ to test the reliability of the variables. As Table III shows, all variables (both dependent and independent) indicating Cronbach's $\alpha$ scores of 0.700 and above are considered reliable and internally consistent (Hair et al., 2010). The results indicate that all the constructs used in this study are reliable (Loan $\cos t=0.887$; Flexibility of loan=0.886; Loan amount adequacy $=0.865 ;$ Loan accessibility $=0.739 ; E G=0.907)$.

In terms of content validity, Parasuraman et al. (1988) argue that the content validity of a construct depends on the extent to which the construct items represent the themes being measured. The constructs used in this study are believed to possess content validity because the constructs were sourced from the entrepreneurship literature such as Angelucci (2015), Kistruck, et.al (2015) and Mahmood and Rosli (2013) for the independent variables, and Storey (1994) and Fatoki (2011) for the dependent variable. For the control variables, content validity is based on studies such as Man et al. (2002), as well as Anderson and Eshima (2013) where similar variables were used. Table III presents the reliability test of the variables used in this study. 
Table III: Cronbach's alpha test of reliability for microcredit factors and employment growth

\begin{tabular}{|c|c|c|c|}
\hline Factors & Cronbach's Alpha & $\begin{array}{c}\text { Cronbach's Alpha based on } \\
\text { standardised items }\end{array}$ & No. of Items \\
\hline (1) Loan Cost & .887 & .893 & 3 \\
\hline (2) Loan Repayment flexibility & .886 & .888 & 3 \\
\hline (3) Loan Amount & .865 & .864 & 3 \\
\hline (4) Loan Accessibility & .739 & .748 & 3 \\
\hline (5) Employment Growth & .907 & .913 & 10 \\
\hline
\end{tabular}




\section{Statistical analyses and results}

Table IV below presents the descriptive statistics in terms of the mean and standard deviations of both the dependent and independent variables and the correlations among the variables. The regression analysis of employment growth, the explanatory and control variables are also presented in Table V. The study adopted a linear regression model to run two sets of regressions which are briefly explained below.

\section{Model 1}

The Model 1 which is the restricted model is performed by engaging the control variables which includes manager's level of education, industry category and business age and the dependent variable which is employment growth. The purpose of executing the model 1 is to determine the variance in the dependent variable that is attributable to the control variables only.

\section{Model 2}

The model 2 which represents the full regression model, is executed by engaging the four independent variables (loan cost, flexibility of loan repayment method, loan amount and loan accessibility), the dependent variable (employment growth) and all the control variables (manager's level of education, industry category and business age). The purpose of executing the model 2 is to determine the variance in the dependent variable that is attributable to all the explanatory variables and the control variables. When the two models are compared, the Adjusted $\mathrm{R}^{2}$ differences will indicate if the explanatory variables have caused a significant change in the relationship. In this study, multicollinearity is not a major concern. This is evidenced by the relatively low intercorrelations among the variables as well as the low variance inflation factors (VIF). The highest VIF value which is 3.393 indicates that the model is relatively strong. To assess the overall fitness of the model, ANOVA $F$-values were also inspected. In the restricted regression model, the $F$-value is 29.101. However, in the full regression model, the F-value is 22.11 which are all significant at 0.000 level. $R^{2}$ is another variable which can indicate the overall fitness of the regression model. In the restricted model, the $R^{2}$ is 0.748 and its adjusted $R^{2}$ is 0.743 . In the full regression model, the $R^{2}$ is 0.843 and its adjusted $R^{2} 0.832$. This explains that both the restricted model and the full regression model can explain $74.3 \%$ and $84.3 \%$ (using adjusted values) respectively of the variances of the dependent variable. 
Table IV: Descriptive Statistics and correlations

\begin{tabular}{|c|c|c|c|c|c|c|c|c|c|c|}
\hline Variable & Mean & SD & Obs & 1 & 2 & 3 & 4 & 5 & 6 & 7 \\
\hline (1) Employment Growth & 4.258 & 0.464 & 506 & - & & & & & & \\
\hline (2) Manager's level of education & 5.090 & 0.656 & 506 & $0.000 * * *$ & - & & & & & \\
\hline (3) Age of Business & 4.136 & 0.492 & 506 & $0.000 * * *$ & $0.048 * *$ & _ & & & & \\
\hline (4) Industry Category & 4.216 & 0.528 & 506 & $0.000 * * *$ & $0.009 * *$ & $0.000 * * *$ & - & & & \\
\hline (5) Loan Cost & 4.224 & 0.780 & 506 & 0.382 & $0.000 * * *$ & $0.090 *$ & 0.447 & _ & & \\
\hline (6) Loan Repayment Flexibility & 4.090 & 0.609 & 506 & $0.000 * * *$ & $0.000 * * *$ & 0.155 & $0.003 * *$ & $0.000 * * *$ & - & \\
\hline (7) Loan Amount & 3.992 & 1.003 & 506 & $0.000 * * *$ & $0.006 * *$ & 0.370 & $0.081^{*}$ & $0.010 * *$ & $0.000 * * *$ & - \\
\hline (8) Loan Accessibility & 4.047 & 0.518 & 506 & $0.000 * * *$ & $0.017 * *$ & $0.000 * * *$ & $0.000 * * *$ & 0.331 & $0.015^{* *}$ & 0.376 \\
\hline
\end{tabular}

Note: The table above shows the descriptive statistics and correlation among all the variables. The levels of significance $(1$-tailed $)$ are $* p<0.1, * * p<0.05$, *** $<<0.01$ 
Table V: Regression analysis of microcredit factors and employment growth among MSEs in Ghana

\begin{tabular}{|c|c|c|c|c|c|c|c|c|}
\hline \multicolumn{9}{|c|}{ Employment Growth } \\
\hline & \multicolumn{4}{|c|}{ Model 1} & \multicolumn{4}{|c|}{ Model 2} \\
\hline & B & SE & $\operatorname{Sig}(\mathbf{p})$ & VIF & B & SE & $\operatorname{Sig}(\mathbf{p})$ & VIF \\
\hline Manager's level of education & $0.096 * *$ & 0.029 & 0.001 & 1.011 & $0.068 * *$ & 0.028 & 0.016 & 1.056 \\
\hline Age of Business & $0.146 * *$ & 0.059 & 0.014 & 2.332 & $0.113^{*}$ & 0.068 & 0.096 & 3.393 \\
\hline Industry Category & $0.190 * *$ & 0.056 & 0.001 & 2.345 & $0.130 * *$ & 0.053 & 0.015 & 2.410 \\
\hline Loan Cost & & & & & $-0.050 * *$ & 0.024 & 0.039 & 1.101 \\
\hline Loan Repayment Flexibility & & & & & $0.121 * * *$ & 0.033 & 0.000 & 1.245 \\
\hline Loan Amount Adequacy & & & & & $0.101 * * *$ & 0.019 & 0.000 & 1.138 \\
\hline Loan Accessibility & & & & & $0.096 *$ & 0.053 & 0.037 & 2.261 \\
\hline$R^{2}$ & $0 \cdot 748$ & & & & 0.843 & & & \\
\hline Adjusted $R^{2}$ & 0.743 & & & & 0.832 & & & \\
\hline ANOVA $F$ & 29.101 & & & & 22.811 & & & \\
\hline Sig. $F$ & 0.000 & & & & 0.000 & & & \\
\hline $\mathbf{N}$ & 506 & & & & 506 & & & \\
\hline
\end{tabular}

Note: The table shows the unstandardised coefficients (B), Standard Error and the VIF. The levels of significance are: $* p<0.1, * * p<0.05, * * * p<0.01$ 
From the full regression model (model 2), loan cost with a $p$-value of 0.039 and a coefficient of -0.050 , makes it statistically significant at $p<0.05$ level. This implies a unit increase in loan cost decreases employment growth by $5 \%$. The first hypothesis, $\boldsymbol{H}_{1 \boldsymbol{a}}$ is therefore accepted regarding the negative correlation between loan cost and employment growth. Secondly, flexible loan repayment with a $p$-value of 0.000 and a coefficient value of 0.121 makes it significant at $p<0.001$ level. This implies a unit increase in flexibility of loan repayment, increases employment growth by $12.1 \%$. In this case, the hypothesis, $\boldsymbol{H 1}_{\boldsymbol{b}}$ is confirmed for flexibility of loan repayment having a positive relationship with employment growth among MSEs in Ghana. Thirdly, loan amount adequacy with a $p$-value of 0.000 and a coefficient value of 0.101 makes it statistically significant at $p<0.001$. This implies a unit increase in loan amount adequacy leads to $10.1 \%$ increase in employment growth. The hypothesis regarding loan amount adequacy, $\boldsymbol{H 1}_{\boldsymbol{c}}$ is therefore accepted. Finally, loan accessibility with a $p$-value of 0.037 and a coefficient value of 0.096 makes it significant at $p<0.05$. A unit increase in loan accessibility will lead to $9.6 \%$ increase in employment growth. The hypothesis, $\boldsymbol{H} \boldsymbol{1}_{\boldsymbol{d}}$ regarding loan accessibility is then accepted in this regard.

Regarding the control variables, both manager's level of education and industry category are statistically significant at $p<0.05$ in both models. However, business age is statistically significant at $p<0.05$ in the restricted model, but statistically significant at $p<0.1$ in the full regression model. The research results, therefore, support $\boldsymbol{H} \boldsymbol{1}_{\boldsymbol{a}}, \boldsymbol{H} \boldsymbol{1}_{\boldsymbol{b}}, \boldsymbol{H} \boldsymbol{1}_{\boldsymbol{c}}$ and $\boldsymbol{H}_{\boldsymbol{c}}$ which implies that there is a positive correlation between loan cost, loan repayment flexibility, loan amount, loan accessibility and employment growth among MSEs in Ghana.

\section{Discussion of empirical results}

As indicated in Table $\mathrm{V}$ above, microcredit was measured using four main variables namely loan cost, loan repayment flexibility, adequacy of loan amount and loan accessibility. The results indicate that loan repayment flexibility, loan amount and loan accessibility are positively correlated with employment growth. However, loan cost is negatively related to the growth of employment among MSEs in Ghana.

The Cost of credit from FNGOs is prohibitive to the growth of MSEs and financial inclusion in Ghana 
The result indicates that loan cost is negatively related to employment growth among MSEs in Ghana $(\mathrm{p}=0.039, \boldsymbol{\beta}=-0.050)$. The cost of credit has been noted to be one of the several challenges facing MSEs in Ghana (Abor and Quartey, 2010). A similar study by Beck and Cull (2014) indicate that the financial system in Africa is shallow, costly and has limited outreach. This makes the cost of credit to be negatively related to employment growth among MSEs in Ghana. Kwakyi (2012) indicate that the cost credit in Ghana has been consistently high and this increases the cost of doing businesses since most MSEs have to borrow at an extremely high cost to engage in business activities. The high cost of borrowing in Ghana is attributed to central governments' excessive public borrowing coupled with poor fiscal policies (Quartey, 2003).

On the average, many financial institutions charge between $6 \%$ to $12 \%$ per month as loan interest and this runs between $72 \%$ and $144 \%$ per annum. In terms of processing fees, the cost ranges from 5\% to $10 \%$ of the loan approved (Gyamfi, 2012). In addition to both the processing fee charged and the interest to be paid monthly, it is common to see many financial institutions withholding between $10 \%$ to $25 \%$ of the approved amount as a cash collateral. This denies the MSE owner the opportunity to use the full amount borrowed from the financial institution. Undoubtedly, this will have a negative impact on the MSE's ability to increase employment if much of the profit made goes into the payment of exorbitant interest on the loan borrowed. One other reason which is attributed to the high cost of borrowing in Ghana, particularly for the MSE sector, is the inability of MSEs to provide the type of collateral needed by financial institutions as a support for loans coupled with their high failure rate. This makes the riskadjusted rate for borrowing to MSEs high comparable to large businesses which are considered less risky (Donou-Adonsoua and Sylwester, 2016). Therefore, the cost of credit relating negatively to employment growth among MSEs is not surprising. Even though FNGOs charge relatively lower interest on their facilities than their commercial counterparts, the truth is that the cost of borrowing in Ghana is very high compared to other jurisdictions and this has led to even the cost of microcredit provided by FNGOs to have a negative impact on the performance of MSEs (Kwakyi, 2012). There is, therefore, the need for a regulatory regime which directs credit specifically to MSEs at an affordable cost to support the employment creation drive of MSEs. Also, there is the need for a holistic effort from all stakeholders in Ghana including government, the private sector, and the Non-profit sectors to support MSEs adequately in the generation of employment. In supporting the growth of MSEs, the provision of a cost-effective credit is a pre-requisite. 
FNGOs offer flexible loans to MSEs which promotes financial inclusion and employment generation in Ghana

The result of this study shows that FNGOs are able to offer flexible loans to MSEs which has a positive impact on their employment growth $(p=0.000, \boldsymbol{\beta}=0.121)$. Generally, the structuring of microcredit to MSEs in Ghana particularly from the commercial microfinance institutions has not been in their favour and this has always pushed MSEs into repayment challenges. Most loan facilities in Ghana are short term and do not take into account the cash flow of the MSE and the gestation period of the project for which the loan has been taken (Gallardo, 2001). Structuring loan repayment to meet the needs of the business helps the cash flow of the business and could prevent loan default since the MSE owner is able to plan loan repayment without any difficulty. The tenor of most loans ranges between three to six months. In rare occasions, such loans are given for a twelve month period. As noted by Donou-Adonsoua and Sylwester (2016), most MSEs struggle with repaying their loans because of the short-term loans which are made available to them. MSEs, therefore, do not have access to long-term loans due to their perceived risk of failure and neither do they also have access to trade credit or leasing opportunities which makes the venture creation process less costly (Abor and Biekpe, 2006; Fatoki, 2011). However, due to the focus of FNGOs on poverty reduction and the promotion of a financially inclusive system in Ghana, the study found FNGOs that are able to offer microcredit to MSEs have a positive impact on MSEs' employment generation ability. This makes the role of FNGOs crucial to the development of MSEs in Ghana since they are able to issue long-term loans to MSEs and support projects with long gestation periods (Batttilana and Dorado, 2010). FNGOs, therefore, need to increase their institutional support to MSEs such as the provision of entrepreneurship training and effective business monitoring which will increase their impact on MSEs.

FNGOs offer loan amounts that are adequate for employment generation and thereby promoting a financial inclusion in Ghana

Loans obtained from FNGOs by MSEs is noted to be adequate and contribute positively to employment growth in Ghana $(p=0.000, \boldsymbol{\beta}=0.101)$. In Ghana, most commercially oriented MFIs in their attempt to manage the risk that is associated with MSEs, abruptly reduce loans applied by MSEs to the barest minimum without considering the size of the business, and the purpose of the loan. The inadequacy of loans to meet the needs of MSEs also pushes them to borrow from multiple financial institutions which further creates repayment challenges as well as further risks to the business (Baklouti and Abdelfettah, 2013). When loans granted to MSEs 
are so small that they fail to be beneficial to their operation, such loans often end in consumption or other uses instead of an investment into the enterprise (Bateman and Chang, 2012). It is recommended that to deal with the risks associated with MSEs, MFIs should be able to grant loans that will be adequate to meet the needs of MSEs. Appropriate credit risk measures should be employed in extending credit facilities to MSEs (Ayayi, 2012). By so doing the perceived risk associated with MSEs will be reduced.

FNGOs provides accessibility to loans which promote employment generation and financial inclusion in Ghana

The results of this study indicate that loan accessibility from FNGOs is positively related to employment growth in Ghana ( $\mathrm{p}=0.037, \boldsymbol{\beta}=0.096$ ). Access to timely loans from FNGOs to meet seasonal and non-seasonal needs of MSEs contributes to employment generation in Ghana. Usually, access to funding is more hectic for MSEs which are located in the rural areas where many financial institutions do not operate (Gallardo, 2001). This makes MSEs borrow from money lenders at very exorbitant rates and this affects the cost of doing business as well as posing repayment challenges (Hamilton and Fox, 1998). However, since most FNGOs in Ghana operate in the rural areas, MSEs are able to have access to timely loans to increase their business activities and cash flow. Undoubtedly, one main factor which can inhibit access to microcredit is the cost (Kwakyi, 2012). However, since the cost of loans from FNGOs seems to have a negative impact on MSE's ability to increase employment growth, it is suggested that the government of Ghana needs to intervene by providing cheap and accessible credit to MSEs for their venture creation purposes (Osei-Assibey, 2011). This will complement the microcredit facilities provided by FNGOs in Ghana.

In summary, from the model presented in this study, $\boldsymbol{H} \boldsymbol{1}_{\boldsymbol{a}}, \boldsymbol{H} \boldsymbol{1}_{\boldsymbol{b}}, \boldsymbol{H} \boldsymbol{1}_{\boldsymbol{c}} \boldsymbol{H} \boldsymbol{1}_{\boldsymbol{d}}$ are accepted. It is important to provide cheap, timely and accessible credit to MSEs for the purposes of effective employment generation in Ghana. The expectation is that such assistance would have an effect on promoting a financially inclusive system in Ghana. In providing microcredit to MSEs the role of FNGOs remains important because of their poverty reduction mission which underpins their financial inclusion strategy.

\section{Conclusion}

In contrast to existing literature on the impact of financial capital on MSE growth (Newman et al. 2014), financial capital provided to MSEs can only be effective in employment generation if it is flexible, adequate and accessible. More importantly, the cost of financial capital impacts 
negatively on MSE's performance. This implies that microcredit even if accessible can have a negative impact on MSE growth when the cost is high. In Ghana, the contribution from MSEs to employment generation as well as to the general economic development is enormous (Frimpong, 2013). MSEs, therefore, need support in terms of access to cheap, reliable, and accessible credit with flexible repayment terms. This study, therefore, suggests that there is the need for all stakeholders in Ghana including the Central Government, financial institutions, FNGOs and the donor community to refocus their attention on the development of MSEs which has the capacity to provide a meaningful employment for the financially excluded individuals. The main aim of this study is to investigate the impact of microcredit on employment generation among MSEs in Ghana. The findings suggest that, for microcredit to have the desired impact on the MSEs in terms of the generation of adequate employment, there is the need for FNGOs to consider loans that have flexible repayment terms coupled with adequate loan amount which meets the operational needs of MSEs. More so, accessibility to microcredit should be improved as well as the cost of it. The major contribution of this study is the fact that, even though FNGOs are very important in the provision of microcredit and the promotion of financial inclusion in Ghana and Africa as a whole, it has received a scanty research attention. Therefore, this is one of the few studies in the Ghanaian context which has highlighted the importance of FNGOs and their role in employment generation and financial inclusion.

\section{Research limitations}

This study has some limitations which are worth mentioning. Firstly, research on FNGOs as one of the main providers of microcredit particularly to the financially excluded in Africa is limited (Dichter, 1999). Therefore, given the few studies in this area, presents a limitation to this study in the sense that there is the lack of opportunity to adequately review existing studies to achieve a wide and an in-depth perspective to the study. Secondly, another limitation of this study is that this research has been conducted in the Volta region which is only one of the ten regions of Ghana. Therefore, even though the sample used in this study is large enough, the generalisation of this study to the whole of Ghana should be done with caution. Finally, this study heavily depended on quantitative data and could have also benefited from a qualitative dimension to contribute to or confirm the findings of this study. 


\section{Recommendations for future research}

The findings from this study highlight some further research areas which future research could be focused. Firstly, future research could focus on commercial microfinance institutions rather than the poverty-oriented FNGOs used in this study to examine the same phenomenon of employment generation through microcredit Secondly, the researchers suggest that future research could be extended beyond the Volta region of Ghana in testing the model used in this study. Probably other regions such as the three Northern regions where several FNGOs operate could be involved. Finally, it is suggested that a mixed research approach could be explored in a future research endeavour of this kind whereby the qualitative findings could be used to confirm or complement the findings in this study. 


\section{References}

Abor J and Biekpe N (2006 ) SMEs' Access to Debt Finance:A Comparison of Male-Owned and Female-Owned Businesses in Ghana. The International Journal of Entrepreneurship and Innovation, 7(2), pp.105-112. Abor J and Quartey P (2010) Issues in SME Development in Ghana and South Africa. International Research Journal of Finance and Economics(39), pp.218-228.

Addae-Korankye, A (2012) Microfinance and Poverty Reduction in Ghana. The Case of Central Region of Ghana. Asian Economic and Financial Review, 2(1), pp.135-141.

Agyapong D (2010) Micro, Small and Medium Enterprises’ Activities, Income Level and Poverty Reduction in Ghana - A Synthesis of Related Literature. International Journal of Business and Management, 5(12), pp.196-205.

Akpalu W Alnaa, E S and Aglobitse B P (2012) Access to microfinance and intra household business decision making: Implication for efficiency of female owned enterprises in Ghana. The Journal of SocioEconomics, 41, pp.513-518.

Alajaty M (2017) Institutional reform and FDI decision in transition economies: A qualitative study of Syria. The International Journal of Entrepreneurship and Innovation, 18(3), pp.164-174.

Ambarkhane, D Singh S A and Venkataramani B (2016). Measuring Financial Inclusion of Indian States. International Journal of Rural Management, 12(1), pp.72-100.

Amoako O I and Matlay, H (2015) Norms and trust-shaping relationships among food-exporting SMEs in Ghana. The International Journal of Entrepreneurship and Innovation, 16(2), pp. 123-134.

Anderson J C and Gerbing, D W (1988) Structural Equation Modeling in practice: A review and recommended two-step approach. Psychological Bulletin, 103(3), pp.411-423.

Andrianova, S Demetriades, P and Shortland A (2008) Government ownership of banks, institutions, and financial development. Journal of Development Economics, 85, pp.218-252.

Angelucci M Karlan D and Zinman, J (2015) Microcredit Impacts: Evidence from a Randomized Microcredit Program Placement Experiment by Compartamos Banco. American Economic Journal. Applied Economics, 7(1), pp.151-182.

Armendáriz de Aghion B and Morduch, J. (2005). The Economics of Microfinance. Cambridge, United Kingdom: The MIT Press .

Ayayi A G (2012) Credit risk assessment in the microfinance industry:An application to a selected group of Vietnamese microfinance institutions and an extension to East Asian and Pacific microfinance institutions. Economics of Transition, 20(1), pp. 37-72.

Babajide A A Adegboye B F and Omankhanlen E A (2015) Financial Inclusion and Economic Growth in Nigeria. International Journal of Economics and Financial Issues, 5(3), pp. 629-637.

Baklouti I and Abdelfettah B (2013) Credit Risk Management in Microfinance :The Conceptual Framework. Journal of Finance and Risk Perspectives, 2(1), pp. 9 - 24.

Bateman M and Chang, H-J (2012) Microfinance and the Illusion of Development: From Hubris to Nemesis in Thirty Years. World Social and Economic Review, 1, pp.13-36.

Batttilana J and Dorado, S (2010). Building sustainable hybrid organisations:The case of commercial microfinance organisations. Academy of Management Journal, 53(6), 1419-1440. 
Bauchet J and Morduch J (2013) Is Micro too Small? Microcredit vs. SME Finance . World Development, 43, pp. 288-297.

Beck T andCull, R (2014) Small- and medium-sized enterprise finance in Africa. Brookings: Africa Growth Initiative.

Beck T and Demirguc-Kunt A (2006). Small and medium-size enterprises: Access to finance as a growth constraint. Journal of Banking \& Finance 30 (2006), 30, pp.2931-2943.

Beck, T Demirgüç-Kunt A and Maksimovic V (2008) Financing patterns around the world: Are small firms different? Journal of Financial Economics, 89(3), pp.467-487 .

Berger N and Udell F G (2006). A more complete conceptual framework for SME finance. Journal of Banking \& Finance, 30, pp.2945-2966.

Bögenhold D and Fachinger U (2007) Micro-Firms and the Margins of Entrepreneurship: The Restructuring of the Labour Market. The International Journal of Entrepreneurship and Innovation, 8(4), pp.281-292.

Brinkmann P, Håkansson, A., ·Butiene, I., Kjærsgard, H., Mortensen, K. B., Martens, J., . . Petrenko, A. (2014). The use of networks as a strategic approach of micro-enterprises in the agri-food sector. The International Journal of Entrepreneurship and Innovation, 115(3), pp. 169-178 .

Bruton, D Ahlstrom D and Puky T (2009) Institutional differences and the development of entrepreneurial ventures: A comparison of the venture capital industries in Latin America and Asia. Journal of International Business Studies, 40(5), pp.762-778.

Bank of Ghana (2015) Licensing Policy \& Guidelines. Retrieved from https://www.bog.gov.gh/privatecontent/Banking_Supervision/REQUIREMENT\%20FOR\%20MFI\%20 LICENCE.pdf

Bureau S and Fendt J (2011) Entrepreneurship in the Informal Economy: Why it Matters. The International Journal of Entrepreneurship and Innovation, 12(2), pp.85-94.

Carbo-Valverde S Rodrguez-Fernandez Francisco and Udell F (2016) Trade Credit, the Financial Crisis, and SME Access to Finance. Journal of Money, Credit and Banking, 48(1), pp.113 - 143.

Claessens,S (2006) Access to Financial Services: A Review of the Issues and Public Policy Objectives. The World Bank Research Observer, 21(2), pp. 207-240.

Cooper C A, Gimeno-Gascon, F.and Woo Y (1994) Initial human and financial capital as predictors of new venture performance. Journal of Business Venturing, 9(5), pp.371-395.

Deb R and Suri T (2013) Endogenous emergence of credit markets: Contracting in response to a new technology in Ghana. Journal of Development Economics, 101, pp.268-283.

Dew N (2006) Institutional entrepreneurship: A Coasian perspective. The International Journal of Entrepreneurship and Innovation, 7(1), pp.13-22.

Dichter T (1999) Case Studies in Microfinance:Non-governmental organizations (NGOs) In Microfinance;Past, Present And Future - An Essay. Retrieved July 27, 2017, from Central Bank of Egypt: http://sme.ebi.gov.eg/Documents/Microfinance/Nongovernmental\%20organizations\%20(NGOs)\%20In\%20Microfinance.pdf

Dickson H Weaver K M and Ho, F (2006). Opportunism in the R\&D alliances of SMES: The roles of the institutional environment and SME size. Journal of Business Venturing, 21, pp.487-513. 
Donou-Adonsoua, F and Sylwester K (2016) Financial development and poverty reduction in developing countries: New evidence from banks and microfinance institutions. Review of Development Finance , 6, pp.82-90.

Dorfleitner GRöhe M and Renier N (2017) The access of microfinance institutions to debt capital: An empirical investigation of microfinance investment vehicles. The Quarterly Review of Economics and Finance, 65, pp.1-15.

Duan H Han X and Yang H (2009)An Analysis of Causes for SMEs Financing Difficulty. International Journal of Business and Management, 4(6), pp.73-75.

Dzansi D Y and AtiaseVY (2014) Reflecting on Micro Finance in Poverty Reduction. Mediterranean Journal of Social Sciences, 5(21), pp.345-352.

Egyir S I (2010) Rural Women and Microfinance in Ghana: Challenges and Prospects. Joint 3rd African Association of Agricultural Economists (AAAE) and 48th Agricultural Economists Association of South Africa (AEASA) Conference, South Africa, September, (pp. pp.19-23). Cape Town.

Faherty U and Stephens S ( 2016) Innovation in micro enterprises:reality or fiction? Journal of Small Business and Enterprise Development, 23(2), pp. 349-362.

Fan Z and Zhang R (2017) Financial Inclusion, Entry Barriers, and Entrepreneurship: Evidence from China. Sustainability, 9, pp. 2-27.

Farja Y Gimmon, E and Greenberg, Z (2017) The developing in the developed:Rural SME growth in Israel. The International Journal of Entrepreneurship and Innovation, 18(1), pp.36-46 .

Fatoki O O (2011) The Impact of Human, Social and Financial Capital on the Performance of Small and Medium-Sized Enterprises (SMEs) in South Africa. Journal of Social Sciences, 29(3), pp.193-204.

Fatoki O and Odeyemi, A. (2010). The determinants of access to trade credit by new SMEs in South Africa. African Journal of Business Management , 4(13), pp. 2763-2770.

Figart, M D (2013). Institutionalist Policies for Financial Inclusion . Journal of Economic Issues, 47(4), pp. 873892.

Frimpong, C Y (2013) SMEs as an engine of social and economic development in Africa. Retrieved May 29, 2017, from Modern Ghana: https://www.modernghana.com/news/478225/1/smes-as-an-engine-ofsocial-and-economic-developme.html

Gallardo J (2001). A Framework for Regulating Microfinance Institutions:The Experience in Ghana and the Philippines. The World Bank.

Ganle K J Afriyie K and Segbefia,Y A (2015). Microcredit: Empowerment and Disempowerment of Rural Women in Ghana. World Development, 66, pp. 335-345.

Ghosh S and Tassel, V E (2013) Funding microfinance under asymmetric information. Journal of Development Economics, 101, pp.8-15.

Gyamfi G D (2012). Assessing the effectiveness of credit risk management techniques of microfinace firms in Accra. Journal of Science and Technology, 32(1), pp. 96-103.

Haag, A and Henschel T (2016) SME lending relationships:A learning perspective. The International Journal of Entrepreneurship and Innovation, 17(3), pp.184-193.

Habib M and Jubb C (2013) NGO, Social Capital and Microfinance: A Conceptual Model. International Journal of Sustainable Development, 6(4), pp.67-78. 
Hajilee M Donna S Y and Metghalcji M (2017) Financial market inclusion,shadow economy and economic growth: New evidence from emerging economies. The Quarterly Review of Economics and Finance, 66, pp.149-158.

Hamilton R T and Fox A M (1998) The financing preferences of small firm owners. International Journal of Entrepreneurial Behaviour \& Research, 4(3), pp. 239-248.

Hancock G R and Mueller R O (2010)The reviewer's guide to quantitative methods in the social sciences. New York: Routledge.

Helms B (2006) Access for All:Building Inclusive Financial Systems (Vol. 1). Washington:, United Staes of America: The International Bank for Reconstruction and Development/The World Bank.

Islam A Nguyen C and Smyth R (2015) Does microfinance change informal lending in village economies? Evidence from Bangladesh. Journal of Banking \& Finance, 50, pp.141-156.

Jahiruddin A Short P Dressler W and Khan M A (2011) Can microcredit worsen poverty? Cases of exacerbated poverty in Bangladesh. Development in Practice, 21(8), pp.1109-.

Kessey D K (2014) Microcredit and the promotion of Small and Medium Enterprises in Informal Sector of Ghana: Lesssons from Experience. Asian Economic and Financial Review, 4(6), pp.768-780.

Khavul S (2010) Microfinance:Creating Opportunities for the Poor? Academy of Mnagement Perspective, 24(3), 58-72.

Kima, D-W Yub, J-S and Hassan M K (2018) Financial inclusion and economic growth in OIC countries. Research in International Business and Finance, 43, pp. 1-14.

Kistruck M G Webb, W J Sutter, J C and Bailey,V A (2015). The double-edged sword of legitimacy in base-of-

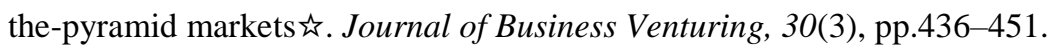

Kolvereid, L (2016) Preference for self-employment: Prediction of new business start-up intentions and efforts. The International Journal of Entrepreneurship and Innovation , 17(2), pp.100-109.

Kwakyi, J. (2012). Financial intermediation and cost of credit in Ghana. Accra: Institute of Economic Affairs.

Laha A and Kuri, P K (2015) Measuring Access of Microfinance on Poverty in India: Towards a Comprehensive Index. International Journal of Financial Management, 5(1), pp.11-17.

Lash, A N (2008) Asymmetric Finance: Issues in Microfinance. The Journal of Economic Asymmetries, 5(1), pp. 93-107.

Lenka K S and Sharma R (2017) Does financial inclusion spur economic growth in India? The Journal of Developing Areas, 51(3), pp.215-228.

Lorenz P M Gamble E J Turnipseed L D and Weaver K M (2015) Do owners and managers really differ? performance in small and medium-sized An examination of satisfaction with overall firm enterprises. The international Journal of Entrepreneurship and Innovation, 16(3), pp. 171-181.

Magableh K I Kharabsheh R and Al-Zubi A K (2011) Determinants and Impact of Training: The Case of SMEs in Jordan. International Journal of Economics and Finance, 3(5), pp.104-116.

Mahmood, R and Rosli M (2013) Microcredit position in micro and small enterprise performance:the Malaysian case. Management Research Review, 36(5), pp.436-453.

Mahmood S Hussain J and Matlay Z (2014) Optimal microfinance loan size and poverty reduction amongst female entrepreneurs in Pakistan. Journal of Small Business and Enterprise Development, 21(2), pp.231-249. 
Mensah S (2004) A review of SME financing schemes in Ghana. A paper Presented at the UNIDO Regional Workshop of Financing Small and Medium Scale Enterprises, Accra, Ghana, 15TH to 16TH March 2004. SEM Capital Ghana Limited. Retrieved June 13, 2017, from http://semcapitalgh.com/downloads/research/SME_Financing_Schemes_in_Ghana.pdf

Meyer L R (2002) The Demand for Flexible Microfinance Products:Lessons from Bangladesh. Journal of International Development, 14, pp.351-368.

Nagler P and Naudé W (2016). Non-farm entrepreneurship in rural sub-Saharan Africa: New empirical evidence. Food Policy, 67, pp.175-191.

Ndlovu G ( 2013). Financial Sector Development and Economic Growth:Evidence from Zimbabwe. International Journal of Economics and Financial Issue, 3(2), pp.435-446.

Newman A Schwarz S and Borgia D (2014) How does microfinance enhance entrepreneurial outcomes in emerging economies? The mediating mechanisms of psychological andsocial capital. International Small Business Journal, 32(2), pp.158-179.

Nielsen S P (2016) Entrepreneurship orientation in policy making:A determinant of collaboration and organizational adaptability in entrepreneurship policy delivery. The International Journal of Entrepreneurship and Innovation, 17(1), pp 43-54.

North D (1990) Institutions, Institutional Change, and Economic Performance. Cambridge: Cambridge University Press.

Ogechi A and Evans O (2017). Financial Inclusion,financial development ad economic diversification in Nigeria. The Journal of Developing Areas, 51(3), pp. 1-15.

Osei-Assibey E (2011). Microfinance in Ghana: A comparative study of performance of the formal verses informal rural financial institutions. Forum for International Development Studies, pp.1-23.

Palamida E Xanthopoulou, D Papagiannidis, S and Stamati, T (2017) Exploring intentions towards human,social and financial capital investments in a turbulent economic environment. The International Journal of Entrepreneurship and Innovation , 18(2), pp.79-90.

Parker C and Praag, C V (2012) The entrepreneur's mode of entry: Business takeover or new venture start? Journal of Business Venturing, 27(1), pp.31-46.

Pathak A A and Varshney S (2017) Challenges faced by women entrepreneurs in rural India: The case of Avika. The International Journal of Entrepreneurship and Innovation, 18(1), pp. 65-72.

Permanyer I (2014) Assessing individuals' deprivation in a multidimensional framework. Journal of Development Economics, 2014, vol. 109, issue C, pages, 106, pp.1-16.

Quartey P (2003) Financing Small and Medium Enterprises (SMEs) in Ghana. Journal of African Business, 4(1), pp.37-55.

Radhika D and Ghosh, M (2013) Financial Inclusion for Inclusive Growth of India - A Study of Indian States. International Journal of Business Management \& Research, 3(1), pp.147-156.

Rajbanshi R Huang, M and Wydick, B (2015 ) Measuring Microfinance: Assessing the Conflict between Practitioners and Researchers with Evidence from Nepal . World Development , 68, pp. 30-47.

Rokhim R Sikatan, A S Lubis W A and Setyawan I M ( 2016). Does microcredit improve wellbeing? Evidence from Indonesia. Humanomics, 32(3), pp. 258-274. 
Sappleton, N, and Lourenco, F (2016) Work satisfaction of the self-employed:The roles of work autonomy, working hours, gender and sector of self-employment. The International Journal of Entrepreneurship and Innovation, 17(2), pp.89-99.

Sarma, M and Pais J (2011) Financial Inclusion and Development. Journal of International Development, 25(5), pp.613-628.

Sarma M and Pais J (2011) Financial Inclusion and Development. Journal of International Development, 23, pp. 613-628.

Scott W (1992) Organizations: Rational, natural, and open systems (2nd ed.). New York: Englewood Cliffs.

Shirokova G and Tsukanova, T (2013). Impact of the domestic institutional environment on the degree of internationalization of SMEs in transition economies. The International Journal of Entrepreneurship and Innovation, 14(3), pp. 193-204.

Sidek S and Mohamad R M (2014) Managerial Competencies and Small Business Growth :Empirical Evidence from Microfinance Participants . International Journal of Mechanical Sciences , 21(1), pp. 39-59.

Snodgrass, R D., and Biggs, T (1996) Industrialization and the Small Firm: Patterns and Policies. San Francisco: International Center for Economic Growth.

Storey J (1994) Understanding the small business Sector. London: Thompson Learning.

Su J Zhai Q and Karlsson T (2016)Beyond Red Tape and Fools: Institutional Theory in Entrepreneurship Research, 1992-2014. Entrepreneurship Theory and Practice, 41(4), pp.1-27.

Swamy V (2014) Financial inclusion, Gender dimension and Economic Impact on Poor Households. World Development, 56, pp. 1-15.

Syed A A and Faisal M A (2011) Managing success factors in entrepreneurial ventures: a behavioral approach. International Journal of Entrepreneurial Behaviour \& Research, 17(5), pp.534-560.

Urban, B (2013) Influence of the institutional environment on entrepreneurial intentions in an emerging economy. The International Journal of Entrepreneurshi and Innovation, 14(3), pp 179-191.

Wellalage N and Locke S (2017) Access to credit by SMEs in South Asia: do women entrepreneurs face discrimination. Research in International Business and Finance, 41, pp. 336-346.

Wilson N and Martin L ( 2015) Entrepreneurial opportunities for all? Entrepreneurial capability and the Capabilities Approach. Internatiional Journal of Entrepreneurship and Innovation, 16(3), pp 159-169.

Wright G (2000) Microfinance Systems: Designing Quality Financial Services for the Poor. Dhaka:

TheUniversity Press Limited.

Yamane T (1967) Statistics, An Introductory Analysis (2nd ed.). New York: Harper. 